\title{
Stable isotopes dissect aquatic food webs from the top to the bottom
}

\section{J. J. Middelburg}

Faculty of Geosciences, Utrecht University, Budapestlaan 4, 3584 CD Utrecht, the Netherlands

Correspondence to: J. J. Middelburg (j.b.m.middelburg@uu.nl)

Received: 5 September 2013 - Published in Biogeosciences Discuss.: 10 September 2013

Revised: 19 February 2014 - Accepted: 13 March 2014 - Published: 28 April 2014

\begin{abstract}
Stable isotopes have been used extensively to study food-web functioning, that is, the flow of energy and matter among organisms. Traditional food-web studies are based on the natural variability of isotopes and are limited to larger organisms that can be physically separated from their environment. Recent developments allow isotope ratio measurements of microbes and this in turn allows the measurement of entire food webs, in other words, from small producers at the bottom to large consumers at the top. Here, I provide a concise review on the use and potential of stable isotopes to reconstruct end-to-end food webs. I will first discuss food web reconstruction based on natural abundances isotope data and will then show that the use of stable isotopes as deliberately added tracers provides complementary information. Finally, challenges and opportunities for end-to-end food web reconstructions in a changing world are discussed.
\end{abstract}

\section{Introduction}

Food webs depict the exchange of matter among organisms within an ecosystem, including the energy flow from basal resources to top predators (Krumins et al., 2013). Biogeochemists and ecologists both study carbon flows within ecosystems but often use different concepts, theories and currencies, because of different research traditions and methodologies. Biogeochemists and microbial ecologists focus on the lower part of the food web because algae, bacteria and archaea govern major element flows and processes, such as primary production and respiration. Their primary currency is biomass, and rate and flux measurements are expressed in quantity per unit volume/area per unit time (Sarmiento and Gruber, 2006). Microbiologists also focus their attention on the algae, bacteria and archaea, but their approach mainly involves molecular biology tools (genomics and proteomics) providing information on identity, diversity and metabolic capabilities of microbial communities. Most pelagic food-web ecologists either focus on phytoplanktonbacteria-zooplankton interactions using biomass and fluxes as currency, or on the higher trophic levels (zooplankton to fishes), and typically use densities, number of individuals and sometimes biomass as model currency (Travers et al., 2007). Similarly, most benthic food-web studies are biased towards metazoans, macrophytes and suspended/sedimentary detritus and do not resolve the microbial domain.

It is unfortunate that differences in research traditions (evolutionary ecology vs. biogeochemistry) and methodology (DNA-based identity vs. counting, biomass or flux measurements) have so far limited integration of food webs from end-to-end: from small producers at the bottom to large consumers at the top of the food web. This information is critical for linking changes in the environment (e.g., global warming, eutrophication, hypoxia, ocean acidification) with the functioning of higher organisms because many environmental impacts go via the lower parts of the food web. Similarly, top predators are thought to impact nutrient cycling in lakes (Carpenter et al., 2001), but are normally ignored in ocean biogeochemistry models. It is for this reason that substantial efforts have been made to integrate different modeling approaches into end-to-end marine ecosystem modeling (Rose et al., 2010; Salihoghu et al., 2013).

Stable isotope analysis (SIA) has emerged as a versatile tool for questions in biogeochemistry, plant and animal physiology, migration patterns, niche definition and shifts, resource use and diet composition, trophic-level estimations and food-web functioning (Fry, 2006; Bouillon et al., 2012). SIA can be applied to all size classes in food webs: from aquatic microbes to whales, from soil fungi to elephants, from sediment bacteria to worms. As such, it may provide an alternative avenue to end-to-end food web studies 
besides ecosystem modeling (Rose et al., 2010). Most stable isotope applications in biogeochemistry and ecology make use of the small natural variations in stable isotope ratios resulting from physical, chemical and biological processes that cause isotope fractionation. These differences in natural abundance stable isotope ratios are primarily generated during primary production, but subsequent heterotrophic processing also contributes (Craig, 1953).

Carbon and nitrogen stable isotopes are most commonly used for elucidating trophic structure and for inferring energy and matter flows in food webs. Stable carbon isotope ratios $\left(\delta^{13} \mathrm{C}\right)$ of plants vary because of differences in isotopic composition of the inorganic carbon substrate used and the photosynthetic pathway (C3 or C4) involved (Smith and Epstein, 1970). These carbon isotope ratios are reflected in the tissue of animals consuming these plants (De Niro and Epstein, 1978) according to the principle "you are what you eat", or more precisely "you are what you assimilate". In a subsequent study De Niro and Epstein (1981) showed that stable nitrogen isotope ratios $\left(\delta^{15} \mathrm{~N}\right)$ of consumers are typically enriched by $2-4 \%$ relative to their diet. Nitrogen isotope ratios can thus be used to estimate trophic position of a consumer (Minagawa and Wada, 1984), while carbon isotope ratios provide information on the eventual carbon/energy sources at the base of the food web (Peterson and Fry, 1987; Post, 2002; Bouillon et al., 2012). This dual-isotope analysis of food webs provides qualitative, objective information about energy flow through food webs and trophic transfers (Fig. 1), and if some assumptions are made it allows quantification of food chain length (Peterson and Fry, 1987; van der Zanden and Rasmussen, 2001) and consumer diets (Phillips et al., 2005; Fry, 2013).

Earth scientists pioneered stable isotope techniques, but technological progress, in particular automated continuousflow, and online isotope ratio mass spectrometry, has made stable isotope analysis widely available. Stable isotope analysis is now a routine procedure in many laboratories and stable isotope ecology has matured and expanded to such an extent that it is nearly impossible, let alone wise, to review all applications in stable isotope ecology and biogeochemistry. Excellent reviews are available for stable isotope use in (experimental) animal ecology (del Rio et al., 2009; Wolf et al., 2009), plant ecology (Dawson et al., 2002), trophic transfers (Boecklen et al., 2011), estuarine biogeochemistry (Bouillon et al., 2012) as well as several dedicated books (Fry, 2006; Michener and Latjha, 2007).

Here, I will review the use of stable isotopes in foodweb reconstructions with a focus on connecting microbial to metazoan food webs and linking natural abundance with tracer applications rather than providing a full account of all studies to date. First, I will evaluate the strengths and weaknesses of natural abundance stable isotope analysis of food webs. Second, most food-web studies are biased towards metazoan consumers and ignore isotopic heterogeneity at the base and concepts such as the microbial loop. The

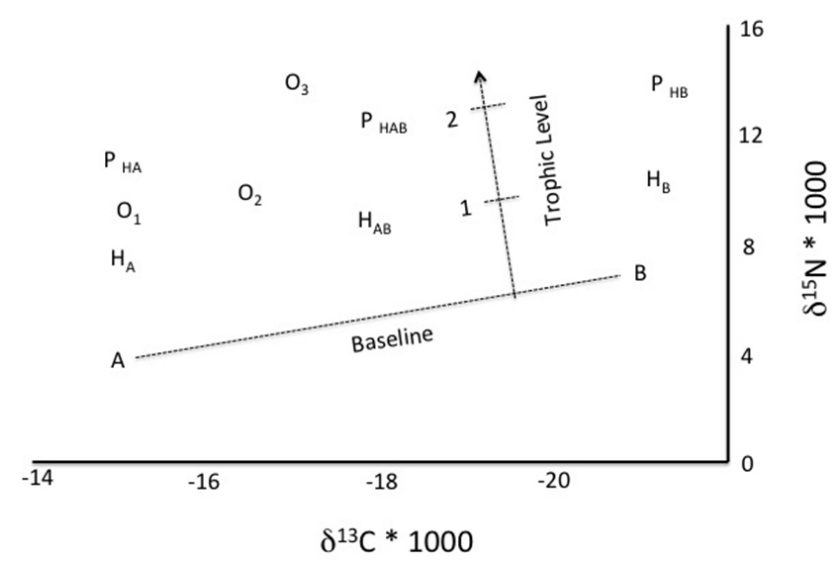

Fig. 1. Conceptual dual isotope plot. This hypothetical two-isotope plot is based on two primary producers $(\mathrm{A}, \mathrm{B})$ that differ in both isotopes and are consumed by specialized herbivores $\left(H_{A}\right.$ and $\left.H_{B}\right)$ and a generalist herbivore $\left(H_{A B}\right.$ depending $50 \%$ on both primary producers). These herbivores are consumed by predators $\left(P_{H A}\right.$, $\left.P_{H A B}, P_{H B}\right)$ as reflected in their increased ${ }^{15} \mathrm{~N}$ content $(y$ axis). Omnivores feed on multiple resources at multiple trophic levels $\left(\mathrm{O}_{1-3}\right)$.

combination of compound-specific isotope analysis of microbial biomarkers and traditional isotope analysis of metazoan consumers is proposed as a fruitful avenue for endto-end food-web analysis complementing model-based approaches. Third, I will review deliberate tracer addition studies of food webs and discuss how they, combined with natural abundance studies, will allow further resolution of foodweb functioning, including crossing domains of life. Fourth, I will discuss approaches to assimilate stable isotope data with the aim to improve food-web reconstructions. In the final section, I will identify a few novel research themes and approaches that can now be explored.

\section{Food-web analysis based on natural abundance stable isotopes}

Stable isotope analysis can be done on small or large organisms, producers as well as consumers, and thus allows linking small organisms at the base of the food web with large consumers at the top (Fig. 1). The basic idea is that the isotope ratio of a consumer reflects that of its diet after correction for isotopic discrimination. This isotopic discrimination during trophic transfers is often small for carbon isotopes $\left(\Delta_{C}=0-1 \%\right.$, De Niro and Epstein, 1978; Post, 2002; van der Zanden and Rasmussen, 2001), therefore neglected, and consumers then primarily reflect the weighted isotopic signals of their resources. However, $\Delta_{\mathrm{C}}$ is not always small (e.g., Dang et al., 2009) and then it has to be taken into account (e.g., Caut et al., 2009). When $\Delta_{C}$ is neglected, a simple twoend-member model can be used to estimate the proportion of 
carbon $\left(p_{\mathrm{C}}\right)$ derived from resource $\mathrm{A}: p_{\mathrm{C}}=\left(\delta^{13} \mathrm{C}_{\text {consumer }^{-}}\right.$

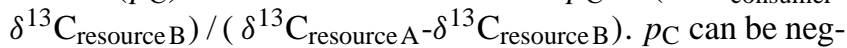
ative or above 1 if an important food resource has not been sampled or included in the mixing model. A consumer relying $25 \%$ on terrestrial plant detritus with a $\delta^{13} \mathrm{C}$ of $-27 \%$ o and $75 \%$ on phytoplankton with a $\delta^{13} \mathrm{C}$ of $-19 \%$ would have a $\delta^{13} \mathrm{C}$ of $-21 \%$.

Nitrogen isotope values can also be used for diet studies, but the systematic enrichment of consumers by 2-4\%o relative to their diet (Minagawa and Wada, 1984) makes $\delta^{15} \mathrm{~N}$ an excellent measure for identifying trophic transfers and omnivory, and for quantifying trophic position. For a simple linear food chain the trophic position (TP) can be directly estimated from $\mathrm{TP}=\left(\delta^{15} \mathrm{~N}_{\text {consumer }^{-}}\right.$ $\left.\delta^{15} \mathrm{~N}_{\text {resource atbase }}\right) / \Delta_{\mathrm{N}}$, where $\Delta_{\mathrm{N}}$ is the enrichment per trophic transfer (2-4\%o) and $\delta^{15} \mathrm{~N}_{\text {resource atbase is the nitro- }}$ gen isotope ratio at the base of the food chain. Similarly, the trophic position for a two-source food web can be calculated from: $\mathrm{TP}=\left(\delta^{15} \mathrm{~N}_{\text {consumer }}-\left[p_{\mathrm{N}} \times \delta^{15} \mathrm{~N}_{\text {resource Aatbase }}+(1-\right.\right.$

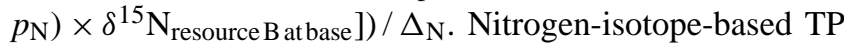
estimates are continuous rather than discrete because they incorporate omnivory (Fig. 1) and they have shown to correlate with organism size and accumulation of contaminants (e.g., Cabana and Rasmussen, 1996).

The accuracy of trophic position estimates depends on a number of factors: (1) the assumption that carbon and nitrogen flow through the food web similarly $\left(p_{\mathrm{C}}=p_{\mathrm{N}}\right.$; i.e., no concentration effect) and that isotopic enrichment of carbon during trophic transfer $\left(\Delta_{C}\right)$ is limited, (2) the accuracy of the nitrogen isotopic enrichment per trophic transfer $\left(\Delta_{\mathrm{N}}\right),(3)$ isotopic heterogeneity among tissues and (4) accurate knowledge of carbon and nitrogen isotope signature of basal resources (Lorrain et al., 2002; Fry, 2006; Phillips, 2012; Phillips and Koch, 2002). The variance in isotopic enrichment per trophic transfer or trophic fractionation $\left(\Delta_{\mathrm{N}}\right)$ has received considerable attention. Nitrogen trophic fractionation appears to depend on the form of excretion, the diet, the tissue analyzed, the taxon and the environment (e.g., Vander Zanden and Rasmussen, 2001; Post, 2002; Vanderklift and Ponsard, 2003; Caut et al., 2010; Auerswald et al., 2010; Bunn et al., 2013). The implications of this variance for trophic position estimates and food-web reconstructions have been discussed in detail (van der Zanden and Rasmussen, 2001; Post, 2002) and progress has been made in understanding why ${ }^{15} \mathrm{~N}$ accumulates (del Rio et al. 2009; Wolf et al., 2009), including use of dynamic energy budget models resolving isotopes (Emmery et al., 2011).

Food-web analysis based on carbon and nitrogen isotopes can in principle reveal the contribution of three (number of isotopes +1 ) resources to the diet of consumers (Fry, 2006). However, there are often more than three resources in aquatic ecosystems; this inspired pioneers in isotope ecology to explore additional isotope systems at natural abundance. Sulphur isotopes $\left(\delta^{34} S\right)$ have shown to be powerful to distinguish between benthic and pelagic primary producers in estu- arine and marine systems (Peterson and Fry, 1998; Connolly et al., 2004). Hydrogen isotopes have been used successfully in fresh-water food-web studies because of the strong separation in $\delta^{2} \mathrm{H}$ between aquatic and terrestrial primary production (Doucett et al., 2007; Cole et al., 2011; Solomon et al., 2011; Cole and Solomon, 2012; Karlsson et al., 2012). This difference is due to the high evaporative stress on emergent vegetation compared to aqueous organisms. Fractionation of hydrogen isotopes during trophic transfer is believed to be limited, but organisms acquire a variable part $(25 \pm 10 \%)$ of their hydrogen from the environment (Solomon et al., 2009; Cole et al., 2011). Natural abundance radiocarbon has been used to identify consumer use of non-contemporary (i.e., aged) organic matter by freshwater fish and birds (Schell, 1983), estuarine bacteria (McCallister et al., 2004), river zooplankton (Caraco et al., 2010) and consumers in lakes (McCallister et al., 2012; Zigah et al., 2012). Although each of these isotopes has its own resolution power to elucidate food webs $\left(\delta S^{34}\right.$ : benthic vs. pelagic, $\delta^{2} \mathrm{H}$ aquatic vs. terrestrial, $\Delta^{14} \mathrm{C}$ modern vs. aged resources), it is through their combination and the combination of multiple isotopes with additional information and numerical mixing models that the next step in resource utilization and food-web reconstruction can be made.

\section{Compound specific isotope analysis allows including microbial domain}

Stable isotope food-web studies have traditionally been limited to larger-sized organisms that can be physically separated and isolated for stable isotope measurements. The smaller members at the base of the food web (Archaea, Bacteria and eukaryotic primary producers) were largely neglected. This is unfortunate because food-web dynamics depends on interactions among species and between species and the environment. Many environmental factors affect in particular members of the lower part of the food web (nutrient, light, temperature). Detailed understanding food-web functioning in a changing world thus requires consideration of the entire food web, including the micro-organisms governing energy and nutrient flows in most ecosystems (Travers et al., 2007; de Kluijver et al., 2013).

Many ecosystems are fueled not only by primary producers within the system, but also by external carbon subsidies (Polis et al., 1997). Rivers, lakes and estuaries receive large quantities of organic matter in particulate and dissolved organic form from the watershed and upstream systems (Middelburg and Herman, 2007; Cole et al., 2007). This allochthonous organic matter is consumed directly or indirectly via bacteria by many consumers in aquatic ecosystems (Cole et al., 2006). Advection of dissolved organic matter in the ocean may subsidize higher trophic levels after processing in the microbial loop (Azam et al., 1983; deLaender et al., 2010). For tracing organic matter flows and food-web 
functioning it is therefore essential to resolve the isotopic composition among bacteria, algae and detritus (dead organic matter) (van Oevelen et al., 2006a).

Direct $\delta^{13} \mathrm{C}$ and $\delta^{15} \mathrm{~N}$ characterization of microbial basal resources is analytically challenging and most food-web studies therefore rely on indirect approaches: either on primary consumers (Cabana and Rasmussen, 1996; vanderZanden et al., 1999; Post, 2002) or proxies for (i.e., indirect measures of) isotope ratios of microscopic organisms (Marty and Planas, 2008). The former approach is most often used and has in the case of long-lived primary consumers (e.g., suspension-feeding bivalves) the advantage that short-term and seasonal variability are integrated. However, putative primary consumers such as Daphnia spp. might as well consume allochthonous, locally produced detrital organic matter or bacterially derived material (van den Meersche et al., 2009; de Kluijver et al., 2012) and thus provide a biased picture of available resources. Moreover, this approach only allows reconstruction of food webs from primary consumers upwards, ignoring the microbial domain and the flows of carbon and nitrogen via the microbial loop (Azam et al., 1983) or the sponge loop (de Goeij et al., 2013). The alternative approach to use bulk organic matter, physically separated size-classes or respired carbon dioxide as proxies for bacterial or algal isotope signatures has its problems as well: micro-organisms are often attached to particles, size-classes may overlap and the isotope signature of carbon respired may differ from that assimilated (e.g., Marty and Planas, 2008). Moreover, basal resources usually have a higher turnover than consumers and short-term and/or seasonal variability should be accounted for (van den Meersche et al., 2009).

Recently, compound-specific isotope analysis (CSIA) of biomarkers has enabled us to include the microbial compartment of food webs (Middelburg et al., 2000; Boschker and Middelburg, 2002; Amelung et al., 2008; Bouillon and Boschker, 2006). Biomarkers are molecules specific for certain (groups of) organisms (Boschker and Middelburg, 2002). Through the CSIA of biomarkers it is now possible to isotopically distinguish between micro-organisms and detritus, hence to detect isotopic heterogeneity among microbial producers (e.g., between diatoms and green algae) and consumers, and to study the transfer of carbon in end-to-end food webs (i.e., from microbes to large metazoans). This resolution was required to estimate the contribution of bacteria and phytoplankton to zooplankton diets (van den Meersche et al., 2009), to elucidate the relative contribution of diatoms and cyanobacteria to the diets of meiofauna and macrofauna in sandy permeable sediments (Evrard et al., 2010, 2012), to distinguish reliance of zooplankton species on green algae and cyanobacteria (Pel et al., 2003; Bontes et al., 2006) and to infer the carbon substrate used by bacteria in macrophytedominated coastal systems (Bouillon and Boschker, 2006; Bouillon et al., 2012).

The above examples were based on a compound-specific isotope analysis of lipids, more specific, polar-lipid derived fatty acids (PLFA). PLFA are very suitable biomarkers because of their relatively easy isotope analysis with GC-CIRMS and because these cell membrane constituents occur in bacteria and eukaryotes and are present in relatively constant amounts in organisms of interest, allowing calculations of organism' biomass from concentrations of specific molecules (Boschker and Middelburg, 2002). Moreover, PLFA rapidly turn over, indicating that they reflect living biomass rather than the remains of organisms (e.g., bacterial necromass). However, specificity of PLFA (for identification of microorganisms) is rather low, in other words, bacteria and eukaryotes can be distinguished quite well from each other, but PLFA spectra of many phytoplankton groups overlap (Dijkman et al., 2009). This implies that resolving among phytoplankton groups should be done with utmost care and requires compositional estimators (Dijkman et al., 2009; van den Meersche et al., 2008). Moreover, PLFA are not very useful in tracing Archaea, the third domain of life, although their role in food webs has been recognized (Thurber et al., 2012). Another concern with the use of PLFA and other biomarkers is the difference in isotopic composition of the biomarker relative to the total cell, because the latter is an emergent property (weighted average) of the wide range of isotopic ratios of individual biochemical fractions or compounds. Individual compounds may differ $>20 \%$ in isotopic composition due to fractionation effects during synthesis and transformation reactions (Hayes, 2001; Schouten et al., 1998; Boschker and Middelburg, 2002; Fiorini et al., 2010). This complicates use of biomarker isotopic data as proxies for the isotopic composition of whole organisms/cells. Typical correction factors between PLFA and total microbial cell isotope values are between 2 and 5\%o (Hayes, 2001; Boschker and Middelburg, 2002). To complicate matters further, laboratory studies have shown differences in lipid composition spectra of organisms because of environmental conditions (temperature, carbon dioxide), viral infections and life stage (Riebesell et al., 2000; Evans et al., 2009; Fiorini et al., 2010). Moreover, there is also substantial variability in $\delta^{13} \mathrm{C}$ among fatty acids (e.g., Schouten et al., 1998; Fiorini et al., 2010). These differences are important for natural abundance ratio studies, because differences in isotope ratios between biomarker and total cell/organism are sometimes similar to differences between resources. However, these differences are of little concern for tracer applications because they are canceled out in the calculation (when the same fatty acids in resource and consumer are compared) and are small ( $\sim$ few $\%$ o) relative to typical enrichments used in tracer studies (tens to hundreds $\%$; see Sect. 4).

Compound-specific isotope analysis is not limited to $\delta^{13} \mathrm{C}$, but may also involve radiocarbon (Cherrier et al., 1999; McCallister et al., 2004), $\delta^{2} \mathrm{H}$ (Sessions et al., 1999) and $\delta^{15} \mathrm{~N}$. These have not yet been explored much in a foodweb context, but for nitrogen isotope analysis of amino acids. CSIA of amino acids in zooplankton revealed that some amino acids (trophic ones such as alanine and glutamic acids) 
become richer in ${ }^{15} \mathrm{~N}$ per trophic transfer, whereas others (source amino acids such as phenylalanine) are not (McClelland and Montoya, 2002; Hannides et al., 2009; Chikaraishi et al., 2009). This allowed them to estimate trophic levels for zooplankton and other consumers, and to derive the $\delta^{15} \mathrm{~N}$ of basal resources. However, the trophic enrichment between glutamic acid and phenylalanine appears to be different for herbivory (plant-animal; 7.6\%o) and carnivory (animalanimal; $4.3 \%$ ), complicating inferences based on compoundspecific $\delta^{15} \mathrm{~N}$ analysis (Germain et al., 2013). Basal resources $\delta^{15} \mathrm{~N}$ values are notoriously difficult to obtain because of high temporal variability due to intense recycling and assimilation of dissolved inorganic nitrogen by heterotrophic bacteria (Kirchman, 1994; Veuger et al., 2005). A pilot study on the $\delta^{15} \mathrm{~N}$ of amino acids revealed systematic differences among prokaryotic and eukaryotic algae (McCarthy et al., 2013) that may be helpful to characterize base-level $\delta^{15} \mathrm{~N}$, particularly when combined with isotopic characterization of D-alanine, as this biomarker occurs in heterotrophic and autotrophic bacteria (Veuger et al., 2005).

\section{Stable isotopes as deliberate tracers in food-web studies}

Although the combination of multiple stable isotopes and isotope mixing models is often sufficient to resolve the problem of overlapping isotope signature of resources, an alternative approach involving deliberate stable isotope addition at tracer level might be useful. Studies during the last decades have shown that it is possible to selectively label primary producers through addition of ${ }^{13} \mathrm{C}$-enriched bicarbonate/carbon dioxide or ${ }^{15} \mathrm{~N}$-enriched ammonium or nitrate (Middelburg et al., 2000; van den Meersche et al., 2011; Pace et al., 2004, 2007; Evrard et al., 2010). Similarly, isotopically labeled dissolved organic matter can be added to label bacteria (van Oevelen et al., 2006a; Guilini et al., 2010) or sponges (De Goeij et al., 2013). Phytodetritus enriched in ${ }^{13} \mathrm{C}$ and/or ${ }^{15} \mathrm{~N}$ can be added to trace the flow of carbon and/or nitrogen from detritus to consumers (Blair et al., 1996; Moodley et al., 2002; Woulds et al., 2007). The isotopically labeled resources are utilized and then part of the added label is assimilated in the consumer and provides a direct measure of the involvement of the specific organism in carbon or nitrogen flows. This information is highly relevant for linking organisms' identity and activity (Boschker et al., 1998).

When designing deliberate additions of stable isotopes to ecosystems, it is not only important to select the tracer $\left({ }^{13} \mathrm{C}\right.$, ${ }^{15} \mathrm{~N}$ ) and the form in which it will be added to the system (organic or inorganic, particulate or dissolved, reduced or oxidized form), but also the addition mode (enclosed vs. open system, pulse or continuous labeling) and the duration of the experiment. Deliberate tracer experiments can be executed in enclosures (e.g., mesocosms) or in situ. The in situ approach has been successfully applied to elucidate food webs in lakes
(Pace et al., 2004, 2007), streams (Hall and Meyer, 1998), estuaries (Hughes et al., 2000), tidal marshes (Gribsholt et al., 2005, 2009), tidal flats (Middelburg et al., 2000; Rossi et al., 2009), coral reefs (de Goeij et al., 2013) and deep-sea sediments (Blair et al., 1996). Heavy isotope-enriched materials have also been added in situ to benthic chambers in coastal (Oakes et al., 2010, 2012) and deep-sea sediments (Moodley et al., 2002; Witte et al., 2003) and to cores implemented at the seafloor (Nomaki et al., 2011).

Tracer levels during experiments can be constant, for example, after the addition of ${ }^{13} \mathrm{C}$-DIC in enclosures with community consumption of ${ }^{13} \mathrm{C}$ being small relative to the stock available, or decline as a consequence of tracer consumption or losses (gas or water exchange). Tracer additions can be continuous or as a single or set of pulses. Continuous tracer additions during the entire experimental period usually aim to maintain a constant tracer level because this facilitates interpretation of the data. A single pulsed addition followed by a chase of the added isotope (pulse-chase experiment) is the most often adopted strategy in in situ experiments, such as whole-ecosystem labeling of open systems and when the stock of the component has high turnover and/or low concentrations (e.g., dissolved ammonium). Multiple tracer additions may sometimes be needed to either maintain constant tracer levels in order to facilitate interpretation or to increase the difference in tracer level between substrate and consumers (van Engeland et al., 2012).

The duration of tracer experiments varies from short, $2 \mathrm{~h}$ incubations for investigating microbial dynamics to multimonth studies of whole ecosystems. The appropriate choice depends on the internal dynamics of the systems to be investigated (short for microbial systems, long for whole ecosystems) and on the organism involved (short for fast-growing organisms at the bottom of the food web to long for slowly growing organisms at the top of the food web). Moreover, shorter experiments are logistically simpler to run than experiments lasting for weeks to months, in particular in open systems and at remote locations. Short duration experiments allow accurate quantification of label transfer from the substrate to primary consumers (e.g., primary and bacterial producers, herbivores), but often do not allow detection of transfers from the basal resources via intermediates to the eventual consumers. Long-lasting experiments, in particular when combined with constant tracer levels/additions, allow tracing flows from the bottom to the top in food webs, but at the expense of explanatory power: label may appear in consumers via multiple pathways. This spreading of added tracers among all consumers is interesting for some research questions (e.g., where does primary producer carbon end up), but this scrambling of label may blur elucidation of pathways. A combination of short-term and long-term experiments is consequently most instructive. Gribsholt and coworkers investigated nitrogen dynamics of tidal-freshwater ecosystems with a pulse-labeling over a 2 -week period (Gribsholt et al., 2005) and over a multi-month period (Gribsholt et 
al., 2009). The former was instructive to identify nitrification and tracer assimilation by emergent vegetation, whereas the latter revealed bacterial immobilization of nitrogen in marsh soils. Similarly, short-term ${ }^{13} \mathrm{C}$ labeling studies have revealed that large organisms have either direct assess to basal resources or via short links (Middelburg et al., 2000; Evrard et al., 2010; Woulds et al., 2009; Moodley et al., 2005). These studies were not designed to investigate label transfer to top predators via long or multiple links and some key secondary or tertiary consumers usually do not incorporate significant amount of tracer. One striking example is the limited incorporation of ${ }^{13} \mathrm{C}$ from benthic algae, bacteria or phytodetritus by nematodes (Guilini et al., 2010; van Oevelen et al., 2006a, 2012).

The addition of heavy isotopes as deliberate tracers is increasingly being combined with natural abundance approaches because each approach has its strengths and weaknesses (Table 1) and they provide complementary food-web information (Herman et al., 2000; Evrard et al., 2010; Van Oevelen et al., 2006b, 2010; Cole et al., 2011; Solomon et al., 2011). Deliberate tracer studies have the advantage of being more conclusive than natural abundance studies because differences in isotope ratios of potential food resources is under experimental control, but isotope addition experiments can only trace dependence on contemporary production, that is, the very same material produced just before the experiment is not included. Moreover, use of complex substrates of unknown composition (e.g., detritus) cannot be traced directly and use of ${ }^{15} \mathrm{~N}$ as a tracer excludes its use as a trophic-level proxy. However, deliberate tracer experiments, when properly designed, also allow accurate mass-budgets to be established. Most food-web studies focus on the transfer of organic matter from one organism to the other and ignore the catabolic processes resulting in the release of carbon dioxide by respiration, and ammonium and urea by excretion. A number of studies involving the addition of ${ }^{13} \mathrm{C}$-labeled organic matter to ecosystems identified that most organic carbon resources are respired rather than assimilated and transferred up in the food web (Moodley et al., 2002; Witte et al., 2003). Similarly, nitrogen flows through the food web can be studied at the same time and with the same currency as nitrogen redox transformation processes (Veuger et al., 2007; van den Meersche et al., 2011).

\section{Assimilating isotope data}

The increasing use of stable isotopes in food-web studies has resulted in the development of models to explore the rich data sets. It is instructive to distinguish between data-assimilation tools and models that consider natural abundance data or tracer data, and for the latter among time-series observations versus time-slice observations. Moreover, isotope modeling studies can be limited to isotope data only (e.g., isotope mix-
Table 1. Strengths and weakness of deliberate tracer and natural abundance stable isotope studies.

\begin{tabular}{|c|c|}
\hline Natural abundance & Deliberate tracer \\
\hline Strengths: & Strengths: \\
\hline $\begin{array}{l}\text { - Isotopes integrate } \\
\text { over longer periods } \\
\text { (weeks to months) } \\
\text { - Samples collected in } \\
\text { the field, no incuba- } \\
\text { tion or experimental } \\
\text { manipulation required } \\
\text { - Trophic-level } \\
\text { estimates }\end{array}$ & $\begin{array}{l}\text { - Conclusive (large dif- } \\
\text { ferences among iso- } \\
\text { tope ratios can be } \\
\text { obtained) } \\
\text { - Versatile: tracer can } \\
\text { be added in differ- } \\
\text { ent forms and differ- } \\
\text { ent combination } \\
\text { - Allows in situ } \\
\text { experimentation }\end{array}$ \\
\hline Weaknesses: & Weaknesses: \\
\hline $\begin{array}{l}\text { - Isotopic differences } \\
\text { among organisms or } \\
\text { resources too small } \\
\text { for }{ }^{13} \mathrm{C} \text { and }{ }^{15} \mathrm{~N} \\
\text { - More sources than } \\
\text { isotopes: underdeter- } \\
\text { mined system } \\
\text { - Trophic fractionation } \\
\text { introduces some } \\
\text { uncertainty }\end{array}$ & $\begin{array}{l}\text { - Traces only contem- } \\
\text { porary production in } \\
\text { enriched area/volume } \\
\text { - No trophic-level esti- } \\
\text { mates if }{ }^{15} \mathrm{~N} \text { is added } \\
\text { as tracer } \\
\text { - Complex substrates } \\
\text { (e.g., detritus) cannot } \\
\text { be reproduced well }\end{array}$ \\
\hline
\end{tabular}

ing models) or include additional data such as the biomass of the organisms (Table 2).

\subsection{Natural abundance data}

Stable isotope data in food-web studies are most often analyzed using isotope-mixing models. Diet inferences and food-web interactions based on isotope mixing models are subject to uncertainty because (1) there is substantial variability in the isotopic compositions of resources and consumers, (2) there is uncertainty in isotopic enrichment per trophic transfer, (3) the isotopic composition of resources are not independent, and (4) because of the complex geometry of mixing polygons (Phillips and Gregg, 2001; Moore and Semmens, 2008; Parnell et al., 2010; Semmens et al., 2009; Phillips, 2012; Fry, 2013). Moreover, there are often more potential resources than the number of isotopes +1 . For these cases, the solution to the isotope mixing problem is mathematically underdetermined (like fitting a straight line through one data point) and thus non-unique (van Oevelen et al., 2010). Isotope mixing models have been developed that can deal with variability in resources, consumers and trophic transfer fractionations, overlapping isotope signatures and 
Table 2. Overview of approaches to analyze stable isotope data.

\begin{tabular}{llll}
\hline Type of data & $\begin{array}{l}\text { Natural abundance } \\
\text { steady state }\end{array}$ & $\begin{array}{l}\text { Tracer } \\
\text { discrete time }\end{array}$ & $\begin{array}{l}\text { Tracer } \\
\text { time series }\end{array}$ \\
\hline $\begin{array}{l}\text { Isotope ratio } \\
\text { (IR) }\end{array}$ & Isotope mixing models & $\begin{array}{l}\text { Specific enrichment }(\Delta \delta \text { or } \\
\text { excess atom fraction })\end{array}$ & $\begin{array}{l}\text { Tracer compartment } \\
\text { models }\end{array}$ \\
IR + biomass & $\begin{array}{l}\text { Inverse models includ- } \\
\text { ing stable isotopes }\end{array}$ & Excess ${ }^{13} \mathrm{C}$ mass balance & $\begin{array}{l}\text { Food-web models re- } \\
\text { solving }{ }^{13} \mathrm{C} \text { and }{ }^{12} \mathrm{C}\end{array}$ \\
\hline
\end{tabular}

multiple resources, and that allow exploring the domain of plausible solutions using techniques such as linear programming or Bayesian inferences (Phillips and Gregg, 2003, Lubetkin and Simenstadt, 2004; Parnell et al., 2010; Bugalhu et al., 2008). Usually a frequency distribution of feasible solutions is provided and these should not be averaged (Phillips and Greg, 2003; Fry, 2013). These state-of-the-art mixing models primarily document the uncertainty of inferences (i.e., range of frequency distribution) and provide information of what is not feasible (i.e., what is outside the frequency distribution), but it is only with inclusion of additional, independent information (e.g., other isotopes, tracers or biomarkers) in the mixing model that better constrained and more robust results can be obtained (van den Meersche et al., 2009).

Stable isotope data have also been used in inverse modeling studies. Inverse modeling of food webs aims to derive quantitative estimates of flows within a food web based on empirical data (biomass and fluxes) and mass balances. However, most data sets are incomplete and uncertain, with the result that the problem is underdetermined and multiple solutions to the inverse problem exist (van Oevelen et al., 2010). Solving the inverse model requires incorporation of additional data such as stable isotopes to alleviate the undersampling problem. One approach is the incorporation of diet information from stable isotope mixing models into the linear inverse model of the food-web network (Pacella et al., 2013). This involves the use of natural abundance stable isotope data in (Bayesian) isotope mixing models to derive the upper and lower bounds on flows as prior information in the linear inverse food-web model. An alternative approach involves the use of the natural abundance stable isotope data directly into the linear inverse model by solving the equations for ${ }^{12} \mathrm{C}$ and ${ }^{13} \mathrm{C}$ together. Effectively the number of massbalances increases, while the number of unknown flows remains similar with the consequence that the solutions are better constrained. This approach has been pioneered by Eldridge et al. (2005) and van Oevelen et al. (2006b). The latter study and van Oevelen et al. (2012) showed that further extension of the inverse model with pulse-chase ${ }^{13} \mathrm{C}$ tracer data provides more resolution in the flows from detritus to consumers.

\subsection{Tracer data}

Tracer experiments are almost never run till steady-state partitioning of tracer among the food-web members has been reached because of logistic and scientific reasons, such as the identification of pathways (see Sect. 4). Depending on the sampling frequency, tracer experiments are modeled and discussed at a single or few time steps, with the implicit assumption that tracer distribution patterns are at steady state, or analyzed with a time-series approach (Table 2; Carpenter et al., 2005).

Tracer studies express the enrichment of a tracer in a consumer always relative to the isotopic composition of the consumer before tracer addition, that is, at time $t=0$. Many tracer studies are expressed in terms of isotopic enrichment $\Delta \delta$ (e.g., for ${ }^{13} \mathrm{C}: \Delta \delta^{13} \mathrm{C}=\delta^{13} \mathrm{C}_{t}-\delta^{13} \mathrm{C}_{t=0}$ ). This presentation has the advantage of being close to the original data, that it is easily calculated and eliminates isotope fractionation, but it is better to use the excess atom fraction, formerly known as atom percent excess (Coplen, 2011), because the isotopic enrichment $\Delta \delta$ is not exact at high enrichment levels $(\delta>1000 \%$ ), as sometimes employed in tracer studies (Fry, 2006). Moreover, isotopic enrichment (irrespective of whether expressed in $\Delta \delta$ or as excess atom fraction) is an intensive variable; the size of the pool is not included in the calculation. Consequently, for a certain flow one would obtain large isotopic enrichments for small pools and small isotopic enrichments for large pools (Boschker and Middelburg, 2002). Accordingly, for interpretation of tracer studies it is essential to report the pool size (biomass) of the consumer before quantitative estimates of flows can be made. Nevertheless isotope enrichment data can be very instructive in identifying the (relative) importance of resources for a certain consumer or the dynamics of consumers in a food web, and it is for this reason that many studies report measured $\delta^{13} \mathrm{C} / \delta^{15} \mathrm{~N}$ as $\Delta \delta$ values (e.g., Hall and Meyer, 1998; Blair et al., 1996; de Goeij et al., 2013; Lengger et al., 2014). When biomass data are available it is recommended to calculate excess ${ }^{13} \mathrm{C}$ or ${ }^{15} \mathrm{~N}$ per unit area or volume for each compartment. Excess tracer mass data allow establishing tracer mass balances, including calculation of percent recovery of tracer. This information is most useful when constructing food-web and ecosystem models (van Oevelen et al., 2006b, 2012; Holmes et al., 2000). 
When isotopic enrichment data are available at multiple time steps it is possible to use dynamic or time-series models. Carpenter et al. (2005) modeled a ${ }^{13} \mathrm{C}$ addition experiment of lakes using three different models: a dual isotope flow model (Cole et al., 2002) resolving mass balances for total carbon and ${ }^{13} \mathrm{C}$, a univariate time-series model and a multivariate autoregression model, each with its pros and cons in terms of data requirement, assumptions, identifiability and goodness of fit. Dynamic models used to explore stable isotope tracer experiments are basically of two categories: (1) tracer compartment models that assume steady state, in other words, constant biomass of consumers and (2) dynamic ecosystem models resolving the dynamics of flows and stock over time. Simple source-sink isotope ratio models have been used to model ${ }^{15} \mathrm{~N}$ in a stream food web (Hamilton et al., 2004), ${ }^{13} \mathrm{C}$ from bacteria in tidal flat sediment food web (van Oevelen et al., 2006a), ${ }^{13} \mathrm{C}$ from phytoplankton to bacteria (Norrman et al., 1995; de Kluijver et al., 2010) and to bacteria and zooplankton (Pace et al., 2007; de Kluijver et al., 2013). The simplicity of these models (e.g., few linkages, steadystate biomass) allowed van Oevelen et al. (2006a) and de Kluijver et al. $(2010,2013)$ to use Bayesian (Markov chainMonte Carlo) approaches to assimilate data and to quantify the model uncertainty. Dynamic ecosystem models that resolve multiple compartments of a food web as a function of time are more demanding in terms of data and modeling skills. Van den Meersche et al. (2004) simulated the transfer of ${ }^{13} \mathrm{C}$-bicarbonate to bacteria via phytoplankton during an experimental bloom with a model with dynamic nutrient pools, producer and consumer biomasses and variable nitrogen internal cell quota. More recently, van den Meersche and coworkers (2011) modeled dual tracer experiments involving ${ }^{13} \mathrm{C}$-bicarbonate, ${ }^{13} \mathrm{C}$-glucose, ${ }^{15} \mathrm{~N}$-nitrate and ${ }^{15} \mathrm{~N}$ ammonium additions to mesocosms and could derive unprecedented detailed information on the nitrogen and carbon flows during an estuarine bloom.

\section{Outlook}

\subsection{Methodological innovation}

Stable isotope studies have contributed much to the elucidation and quantification of food-web interactions and the flows of carbon and nitrogen through ecosystems. This progress would not have happened without the availability of continuous flow isotope ratio mass spectrometers (CF-IRMS) since the 1990s. The wealth of isotope data has stimulated modelers to develop sophisticated, Bayesian inference-based isotope-mixing models to extract quantitative food-web data that take into account the natural variability and uncertainty. The majority of food-web studies are limited to carbon and nitrogen isotopes because of their ease of measurement, and to larger-sized organisms that can be physically separated and then analyzed by CF-IRMS. Recent improvements in technology now allow the measurement of $\delta^{13} \mathrm{C}, \delta^{15} \mathrm{~N}$ and $\delta^{34} \mathrm{~S}$ simultaneously on small samples (Hansen et al., 2009). This will enable more accurate and complete reconstruction of food-web interactions.

A growing number of ecological laboratories have or will soon have access to gas chromatography-combustion isotope ratio mass spectrometry (GC-C-IRMS) and CSIA of biomarkers will no doubt extend existing stable isotope studies to the bottom of the food web. Resolving isotopic heterogeneity at the base of the food web, in the microbial domain, will for some time involve a trade-off between on the one hand the resolution in taxonomy and on the other hand the accurate quantification of tracer assimilation and thus organism activity (Fig. 2). While biomarker approaches have provided pivotal knowledge on the carbon isotopic characteristics of microbes, there is very little knowledge on other isotopes (Zhang et al., 2009) and on protozoans that are too small to be physically isolated for isotope determination (e.g., ciliates), yet may govern the energy flow from microbes to putative primary consumers considered in most stable isotope food-web studies. New technological developments such as microcombustion and liquid chromatography isotope ratio mass spectrometry (LC-IRMS; Boschker et al., 2008) and nanoSIMS (secondary ion mass spectrometry at submicrometer scale resolution; Wagner, 2009) may be needed to close this gap in our food-web studies. LC-IRMS will allow simple and rapid analysis of the carbon isotope composition of dissolved organic matter in freshwater systems and of amino acids and carbohydrates that so far have been underexploited in food-web studies. The microcombustion device of LCIRMS has been used successfully to analyze the carbon isotopic composition of 16S-RNA (Miyatake et al., 2009, 2013). NanoSIMS enables users to quantify multiple isotope ratios at subcellular level within a spatial context, and a pilot study showed its potential for analyzing tracer uptake in zooplankton (Eybe et al., 2009).

The recent development of online isotope analysis by cavity ring-down spectrometry has the potential to study carbon cycling from microbial to ecosystem scales (Maher et al., 2013). More specifically, the real-time monitoring of carbon stable isotope of carbon dioxide and methane allows accurate, high-resolution quantification of respiration and fermentation at the system level. Accordingly, new developments in analytical methods provide not only more data at higher resolution, for smaller organisms, for more isotopes and with spatial context, but they will also facilitate integrated ecosystem assessments because assimilation and respiration processes will be studied with the same currency.

\subsection{End-to-end food webs}

Understanding the carbon and nutrient flows between and within ecosystems is essential to advance our knowledge on biogeochemical cycling and ecosystem functioning. Food webs are often described in terms of the herbivory or green 


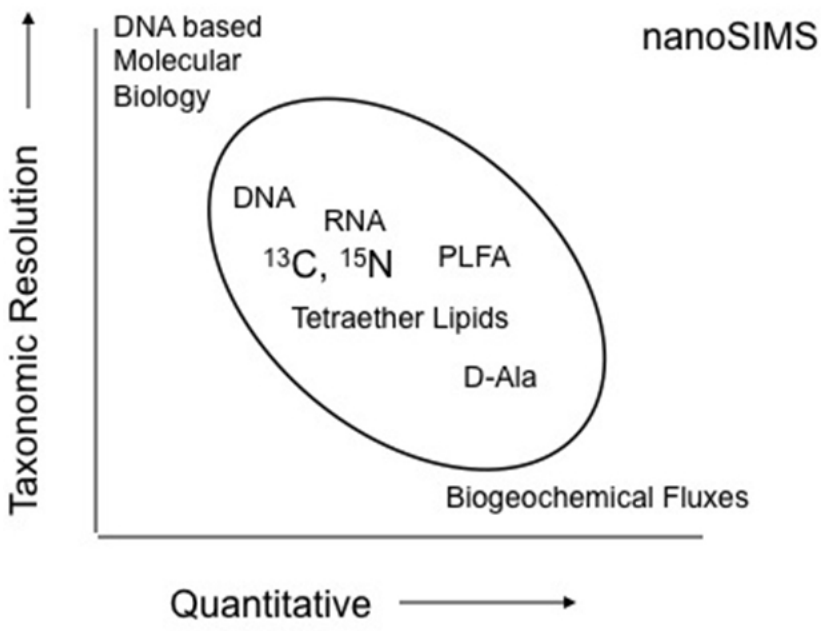

Fig. 2. Conceptual picture of the trade-offs between identity of organism and accurate biogeochemical flux measurement using (microbial) biomarkers. Biogeochemical rates measurement (often based on isotope tracer techniques) provide accurate quantification but no information on the identity of the organisms involved. Molecular biology tools provide high-quality information on the presence and potential capabilities of organisms but limited information on in situ rates. Compound-specific isotope characterization of biomarkers (DNA, RNA, PLFA, Tetraether lipids, D-alanine) in combination with tracer techniques provide rate as well as identity information but with low-to-moderate taxonomic resolution and intermediate accuracy. NanoSIMS can provide individual cell isotope ratio measurements and thus provides high accuracy and high taxonomic resolution, as well as spatial context.

pathway involving plant-herbivory-predator chains or the brown, detritus-microbial loop (detritus-bacteria-metazoan consumers), but these two pathways are just the endmembers of a continuum of parallel, interacting food webs (Legendre and Rassoulzadegan, 1995; Krumins et al., 2013). There is growing awareness that many pelagic ecosystems receive substantial organic matter subsidies from other ecosystems and that consumers utilize both green and brown energy (Cole et al., 2006; Pace et al., 2007; van den Meersche et al., 2009). Similarly, traditional benthic food-web reconstructions are based on utilization of particulate detrital organic matter of variable qualities and do not consider herbivory or grazing on local primary production, such as benthic algae (Gattuso et al., 2006) or chemoautotrophs (Middelburg, 2011; Molari et al., 2013). Recently, de Goeij et al. (2013) identified that cavity sponges in reef systems utilize dissolved organic matter and produce particulate detritus that then becomes available for the consumers. This sponge loop was identified using ${ }^{13} \mathrm{C}$ and ${ }^{15} \mathrm{~N}$ as deliberate tracers in in situ experiments.

Stable isotope studies should in principle be able to resolve the green and brown pathways in food webs. However, most pelagic food-web reconstruction using stable isotopes are based on the green pathway and use phytoplankton or a proxy for phytoplankton (seston or primary consumer) as a basal resource. Challenges are to account for differences in the turnover of isotopes among primary producers and large consumers, differences in lipid content, differences in isotope ratios among tissues/compounds and analytical limitations to resolve the nitrogen isotopic composition of primary producers. In real food webs where green and brown pathways interact, there are challenges in identifying trophic levels because bacteria living on locally produced or external organic matter often assimilate dissolved nitrogen substrates from the environment with consequences for their ${ }^{15} \mathrm{~N}$ signature (Caraco et al., 1998). For any consumer that receives a fraction of its carbon and nitrogen via the microbial loop, it will be very difficult if not impossible to infer its trophic level. Trophic-level estimates based on ${ }^{15} \mathrm{~N}$ data to date ignore bacterial nitrogen assimilation and as such are subject to uncertainty in ecosystems involving substantial energy flow from detrital resources.

More than 20 years ago Hochberg and Lawton (1990) expressed the need to study the competition between kingdoms of life because of its ecological and evolutionary implications. This has not been followed up much. However, we now have the tools. By deliberately adding heavy isotopes to food webs and subsequent tracing of added label in organisms of different domains of life, we can now directly investigate the competition between bacteria, foraminifera and metazoans for the resource (Middelburg et al., 2000; Moodley et al., 2002; Woulds et al., 2007). Van Nugteren et al. (2009) employed ${ }^{13} \mathrm{C}$ as a tracer to study the competition between sediment bacteria and a facultative detrivorous worm and identified that the spatial distribution of resources governed the relative use of the labile carbon added. Vogel et al. (2014) used nanoSIMS with ${ }^{13} \mathrm{C}$ - and ${ }^{15} \mathrm{~N}$-labeled litter to show that submicron structures provide preferential spots for organic matter sequestration in soils. Since ${ }^{13} \mathrm{C}$ can also be incorporated into archaeal biomarkers, it would in principle be possible to study the relative use of resources by archaea, bacteria, protozoa and metazoans. This is analytically challenging, but Nomaki et al. (2011) have documented the transfer of ${ }^{13} \mathrm{C}$ from dissolved organic carbon and phytodetritus to Archaea, foraminifera and metazoans. This suggests that all three domains of life in a food web may have almost direct access to detrital resources. However, Lengger et al. (2014) could not detect significant ${ }^{13} \mathrm{C}$-label incorporation in thaumarchaea derived intact polar lipids while bacteria assimilated the added carbon, indicating that Archaea were not important in processing labile organic carbon in Iceland shelf sediments. Whatever their role may be in organic matter processing, there is a need for studies investigating archivory (Thurber et al., 2012). 


\section{Summary}

Stable isotopes are increasingly being used to elucidate and quantify food-web functioning and to identify the carbon and nitrogen flows through ecosystems. Stable isotope measurements can be performed on inorganic substrates, detrital and living organic matter. This provides the unique opportunity to use the same currency for single-celled and large organisms and for the living and dead organic matter, circumventing the problems associated with traditional currencies of the different branches of ecology. Stable isotopes can be used at natural abundance by making use of the small, systematic differences in ratios among organisms, as well as deliberately added tracers to focus on specific processes or organisms. The combination of tracer and natural abundance studies is very powerful since both approaches have their pros and cons. The use of stable isotopes as tracers also allows accurate quantification of ecosystem budgets, since not only assimilation but also respiration can be estimated. Stable isotopes also enable direct linking of biodiversity (identity of organisms) and ecosystem functioning (primary or secondary production via incorporation of isotope in organisms, respiration, nitrogen transformations) and as such may help to improve our predictive capabilities of biogeochemical cycles in a changing world. Deliberate tracer experiments have been pivotal to elucidate the ecosystem-level response of pelagic ecosystems to ocean acidification (de Kluijver et al., 2010, 2013) and benthic ecosystems to hypoxia and recovery from hypoxia (Woulds et al., 2007, 2009; Rossi et al., 2009).

Acknowledgements. J. Cole and A. de Kluijver read the first draft and two anonymous referees provided constructive feedback and stimulated the author to synthesize literature on data assimilation procedures.

Edited by: D. Gillikin

\section{References}

Amelung, W., Brodowski, S., Sandhage-Hofmann, A., and Bol, R.: Combining biomarker with stable isotope analyses for assessing the transformation and turnover of soil organic matter, Adv. Agron. 100, 155-250, 2008.

Auerswald, K., Wittmer, M. H. O. M., Zazzo, A., Schaeufele, R., and Schnyder, H.: Biases in the analysis of stable isotope discrimination in food webs, J. Appl. Ecol., 47, 936-941, doi:10.1111/j.1365-2664.2009.01764.x, 2010.

Azam, F., Fenchel, T., Field, J. G., Gray, J. S., Meyerreil, L. A., and Thingstad, F.: The Ecological Role of Water-Column Microbes in the Sea, Mar. Ecol.-Prog. Ser., 10, 257-263, doi:10.3354/meps010257, 1983.

Blair, N. E., Levin, L. A., DeMaster, D. J., and Plaia, G.: The shortterm fate of fresh algal carbon in continental slope sediments, Limnol. Oceanogr., 41, 1208-1219, 1996.

Boecklen, W. J., Yarnes, C. T., Cook, B. A., and James, A. C.: On the Use of Stable Isotopes in Trophic Ecology, Annu.
Rev. Ecol. Evol. S., 42, 411-440, doi:10.1146/annurev-ecolsys102209-144726, 2011.

Bontes, B. M., Pel, R., Ibelings, B. W., Boschker, H. T. S., Middelburg, J. J., and Van Donk, E.: The effects of biomanipulation on the biogeochemistry, carbon isotopic composition and pelagic food web relations of a shallow lake, Biogeosciences, 3, 69-83, doi:10.5194/bg-3-69-2006, 2006.

Boschker, H. T. S. and Middelburg, J. J.: Stable isotopes and biomarkers in microbial ecology, FEMS Microbiol. Ecol., 40, 85-95, doi:10.1111/j.1574-6941.2002.tb00940.x, 2002.

Boschker, H. T. S., Nold, S. C., Wellsbury, P., Bos, D., de Graaf, W., Pel, R., Parkes, R. J., and Cappenberg, T. E.: Direct linking of microbial populations to specific biogeochemical processes by C-13-labelling of biomarkers, Nature, 392, 801-805, doi:10.1038/33900, 1998.

Boschker, H. T. S., Moerdijk-Poortvliet, T. C. W., van Breugel, P., Houtekamer, M., and Middelburg, J. J.: A versatile method for stable carbon isotope analysis of carbohydrates by high-performance liquid chromatography/isotope ratio mass spectrometry, Rapid Commun. Mass Sp., 22, 3902-3908, doi:10.1002/rcm.3804, 2008.

Bouillon, S. and Boschker, H. T. S.: Bacterial carbon sources in coastal sediments: a cross-system analysis based on stable isotope data of biomarkers, Biogeosciences, 3, 175-185, doi:10.5194/bg-3-175-2006, 2006.

Bouillon, S., Gillikin, D. P., and Connolly, R. M.: Use of stable isotopes to understand food webs and ecosystem functioning in estuaries, in: Treatise on Estuarine and Coastal Science, edited by: Wolanski, E. and McLusky, D. S., 7, 143-173, Waltham: Academic Press, 2012.

Bugalho, M. N., Barcia, P., Caldeira, M. C., and Cerdeira, J. O.: Stable isotopes as ecological tracers: an efficient method for assessing the contribution of multiple sources to mixtures, Biogeosciences, 5, 1351-1359, doi:10.5194/bg-5-1351-2008, 2008.

Bunn, S. E., Leigh, C., and Jardine, T. D: Diet-tissue fractionation of $\delta 15 \mathrm{~N}$ by consumers from streams and rivers Limnol. Oceanogr., 58, 765-773 doi:10.4319/lo.2013.58.3.0765, 2013.

Cabana, G. and Rasmussen, J. B.: Comparison of aquatic food chains using nitrogen isotopes, P. Natl. Acad. Sci. USA, 93, 10844-10847, doi:10.1073/pnas.93.20.10844, 1996.

Caraco, N., Bauer, J. E., Cole, J. J., Petsch, S., and Raymond, P.: Millennial-aged organic carbon subsidies to a modern river food web, Ecology, 91, 2385-2393, doi:10.1890/09-0330.1, 2010.

Caraco, N. F., Lampman, G. G., Cole, J. J., Limburg, K. E., Pace, M. L., and Fischer, D. T.: Microbial assimilation of DIN in a nitrogen rich estuary: implications for food quality and isotope studies, Mar. Ecol.-Prog. Ser., 167, 59-71, 1998.

Carpenter, S. R., Cole, J. J., Hodgson, J. R., Kitchell, J. F., Pace, M. L., Bade, D., Cottingham, K. L., Essington, T. E., Houser, J. N., and Schindler, D. E.: Trophic cascades, nutrients, and lake productivity: whole-lake experiments, Ecol. Monogr., 71, 163-186, doi:10.1890/00129615(2001)071[0163:TCNALP]2.0.CO;2, 2001.

Carpenter, S. R., Cole, J. J., Pace, M. L., Van de Bogert, M., Bade D. L., Bastviken, D., Gille, C., Hodgson, J. R., Kitchell, J. F., and Kritzberg, E. S.: Ecosystem subsidies: Terrestrial support of aquatic food webs from ${ }^{13} \mathrm{C}$ addition to contrasting lakes, Ecology, 86, 2737-2750, 2005. 
Caut, S., Angulo, E., and Courchamp, F.: Variation in discrimination factors $\left(\Delta 15 \mathrm{~N}\right.$ and $\left.\Delta^{13} \mathrm{C}\right)$ : the effect of diet isotopic values and applications for diet reconstruction, J. Appl. Ecol., 46, 443-453, 2009.

Caut, S., Angulo, E., Courchamp, F., and Figuerola, J.: Trophic experiments to estimate isotope discrimination factors, J. Appl. Ecol., 47, 948-954, doi:10.1111/j.1365-2664.2010.01832.x, 2010.

Cherrier, J., Bauer, J. E., Druffel, E. R. M., Coffin, R. B., and Chanton, J. P.: Radiocarbon in marine bacteria: Evidence for the ages of assimilated carbon, Limnol. Oceanogr., 44, 730-736, 1999.

Chikaraishi, Y., Ogawa, N. O., Kashiyama, Y., Takano, Y., Suga, H., Tomitani, A., Miyashita, H., Kitazato, H., and Ohkouchi, N.: Determination of aquatic food-web structure based on compoundspecific nitrogen isotopic composition of amino acids, Limnol. Oceanogr.-Meth., 7, 740-750, 2009.

Cole, J. J. and Solomon, C. T.: Terrestrial support of zebra mussels and the Hudson River food web: A multi-isotope, Bayesian analysis, Limnol. Oceanogr., 57, 1802-1815, 2012.

Cole, J. J., Carpenter, S. R., Kitchell, J. F., and Pace, M. L.: Pathways of organic $\mathrm{C}$ utilization in small lakes: Results from a whole-lake ${ }^{13} \mathrm{C}$ addition and coupled model, Limnol. Oceanogr., 47, 1664-1675, 2002.

Cole, J. J., Carpenter, S. R., Pace, M. L., Van de Bogert, M. C., Kitchell, J. L., and Hodgson, J. R.: Differential support of lake food webs by three types of terrestrial organic carbon, Ecol. Lett., 9, 558-568, doi:10.1111/j.1461-0248.2006.00898.x, 2006.

Cole, J. J., Prairie, Y. T., Caraco, N. F., McDowell, W. H., Tranvik, L. J., Striegl, R. G., Duarte, C. M., Kortelainen, P., Downing, J. A., Middelburg, J. J., and Melack, J.: Plumbing the global carbon cycle: Integrating inland waters into the terrestrial carbon budget, Ecosystems, 10, 171-184, doi:10.1007/s10021-006-9013-8, 2007.

Cole, J. J., Carpenter, S. R., Kitchell, J., Pace, M. L., Solomon, C. T., and Weidel, B.: Strong evidence for terrestrial support of zooplankton in small lakes based on stable isotopes of carbon, nitrogen, and hydrogen, P. Natl. Acad. Sci. USA, 108, 1975-1980, doi:10.1073/pnas.1012807108, 2011.

Connolly, R. M., Guest, M. A., Melville, A. J., and Oakes, J. M.: Sulfur stable isotopes separate producers in marine foodweb analysis, Oecologia, 138, 161-167, doi:10.1007/s00442003-1415-0, 2004.

Coplen, T. B.: Guidelines and recommended terms for expression of stable-isotope-ratio and gas-ratio measurement results, Rapid Commun. Mass Sp., 25, 2538-2560, 2011.

Craig, H.: The Geochemistry of the Stable Carbon Isotopes, Geochim. Cosmochim. Ac., 3, 53-92, doi:10.1016/00167037(53)90001-5, 1953.

Dang, C., Sauriau, P. G., Savoye, N., Caill-Milly, N., Martinez, P., Haure, J., Millaret, C., and de Montaudouin, X.: Determination of diet in Manila clams by spatial analysis of stable isotopes, Mar. Ecol.-Prog. Ser., 387, 167-177, 2009.

Dawson, T. E., Mambelli, S., Plamboeck, A. H., Templer, P. H., and Tu, K. P.: Stable isotopes in plant ecology, Annu. Rev. Ecol. Syst., 33, 507-559, doi:10.1146/annurev.ecolsys.33.020602.095451, 2002.

de Goeij, J. M., van Oevelen, D., Vermeij, M. J. A., Osinga, R., Middelburg, J. J., de Goeij, A. F. P. M., and Admiraal, W.: Surviving in a Marine Desert: The Sponge Loop Re- tains Resources Within Coral Reefs, Science, 342, 108-110, doi:10.1126/science.1241981, 2013.

de Kluijver, A., Soetaert, K., Schulz, K. G., Riebesell, U., Bellerby, R. G. J., and Middelburg, J. J.: Phytoplankton-bacteria coupling under elevated $\mathrm{CO}_{2}$ levels: a stable isotope labelling study, Biogeosciences, 7, 3783-3797, doi:10.5194/bg-7-3783-2010, 2010.

de Kluijver, A., Yu, J., Houtekamer, M., Middelburg, J. J., and Liu, Z.: Cyanobacteria as a carbon source for zooplankton in eutrophic Lake Taihu, China, measured by C-13 labeling and fatty acid biomarkers, Limnol. Oceanogr., 57, 1245-1254, doi:10.4319/lo.2012.57.4.1245, 2012.

de Kluijver, A., Soetaert, K., Czerny, J., Schulz, K. G., Boxhammer, T., Riebesell, U., and Middelburg, J. J.: A ${ }^{13} \mathrm{C}$ labelling study on carbon fluxes in Arctic plankton communities under elevated $\mathrm{CO}_{2}$ levels, Biogeosciences, 10, 1425-1440, doi:10.5194/bg-101425-2013, 2013.

De Laender, F., Van Oevelen, D., Soetaert, K., and Middelburg, J. J.: Carbon transfer in herbivore- and microbial loopdominated pelagic food webs in the southern Barents Sea during spring and summer, Mar. Ecol.-Prog. Ser., 398, 93-107, doi:10.3354/meps08335, 2010.

del Rio, C. M., Wolf, N., Carleton, S. A., and Gannes, L. Z.: Isotopic ecology ten years after a call for more laboratory experiments, Biol. Rev., 84, 91-111, doi:10.1111/j.1469-185X.2008.00064.x, 2009.

Deniro, M. J. and Epstein, S.: Influence of diet on the distribution of carbon isotopes in animals, Geochim. Cosmochim. Ac., 42, 495-506, 1978.

Deniro, M. J. and Epstein, S.: Influence of Diet on the Distribution of Nitrogen Isotopes in Animals, Geochim. Cosmochim. Ac., 45, 341-351, doi:10.1016/0016-7037(81)90244-1, 1981.

Doucett, R. R., Marks, J. C., Blinn, D. W., Caron, M., and Hungate, B. A.: Measuring terrestrial subsidies to aquatic food webs using stable isotopes of hydrogen, Ecology, 88, 1587-1592, doi:10.1890/06-1184, 2007.

Dijkman, N. A., Boschker, H. T. S., Middelburg, J. J., and Kromkamp, J. C.: Group-specific primary production based on stable-isotope labeling of phospholipid-derived fatty acids, Limnol. Oceanogr.-Meth., 7, 612-625, 2009.

Eldridge, P. M., Cifuentes, L. A., and Kaldy, J. E... Development of a stable isotope constraint system for estuarine food web models, Mar. Ecol.-Prog. Ser. 303, 73-90, 2005.

Emmery, A., Lefebvre, S., Alunno-Bruscia, M., and Kooijman, S. A. L. M.: Understanding the dynamics of $\partial^{13} \mathrm{C}$ and $\partial^{15} \mathrm{~N}$ in soft tissues of the bivalve Crassostrea gigas facing environmental fluctuations in the context of Dynamic Energy Budgets (DEB), J. Sea Res., 66, 361-371, 2011.

Evans, C., Pond, D. W., and Wilson, W. H.: Changes in Emiliania huxleyi fatty acid profiles during infection with E-huxleyi virus86: physiological and ecological implications, Aquat. Microb. Ecol., 55, 219-228, 2009.

Evrard, V., Soetaert, K., Heip, C. H. R., Huettel, M., Xenopoulos, M. A., and Middelburg, J. J.: Carbon and nitrogen flows through the benthic food web of a photic subtidal sandy sediment, Mar. Ecol.-Prog. Ser., 416, 1-16, doi:10.3354/meps08770, 2010.

Evrard, V., Huettel, M., Cook, P. L. M., Soetaert, K., Heip, C. H. R., and Middelburg, J. J.: Importance of phytodetritus and microphytobenthos for heterotrophs in a shallow subtidal sandy sediment, 
Mar. Ecol.-Prog. Ser., 455, 13-31, doi:10.3354/meps09676, 2012.

Eybe, T. Bohn, T., Audinot, J. N., Udelhoven, T., Cauchie, H. M., Migeon, H. N., and Hoffmann. L.: Uptake Visualization of Deltamethrin by Nano-SIMS and Acute Toxicity to the Water Flea Daphnia magna, Chemosphere, 76, 134-140, 2009.

Fiorini, S., Gattuso J. P., van Rijswijk, P., and Middelburg, J. J.: Coccolithophores lipid and carbon isotope composition and their variability related to changes in seawater carbonate chemistry, J. Exp. Mar. Biol. Ecol., 394, 74-85, 2010.

Fry, B.: Stable isotope ecology, Springer, Dordrecht, 2006.

Fry, B.: Alternative approaches for solving underdetermined isotope mixing problems, Mar. Ecol.-Prog. Ser., 472, 1-13, doi:10.3354/meps10168, 2013.

Gattuso, J.-P., Gentili, B., Duarte, C. M., Kleypas, J. A., Middelburg, J. J., and Antoine, D.: Light availability in the coastal ocean: impact on the distribution of benthic photosynthetic organisms and their contribution to primary production, Biogeosciences, 3, 489-513, doi:10.5194/bg-3-489-2006, 2006.

Germain, L. R., Koch, P. L., Harvey, J., and McCarthy, M. D.: Nitrogen isotope fractionation in amino acids from harbor seals: implications for compound-specific trophic position calculations, Mar. Ecol.-Prog. Ser., 482, 265-277, doi:10.3354/meps10257, 2013.

Gribsholt, B., Boschker, H. T. S., Struyf, E., Andersson, M., Tramper, A., De Brabandere, L., van Damme, S., Brion, N., Meire, P., Dehairs, F., Middelburg, J. J., and Heip, C. H. R.: Nitrogen processing in a tidal freshwater marsh: A whole-ecosystem (15)N labeling study, Limnol. Oceanogr., 50, 1945-1959, 2005.

Gribsholt, B., Veuger, B., Tramper, A., Middelburg, J. J., and Boschker, H. T. S.: Long-term N-15-nitrogen retention in tidal freshwater marsh sediment: Elucidating the microbial contribution, Limnol. Oceanogr., 54, 13-22, doi:10.4319/lo.2009.54.1.0013, 2009.

Guilini, K., Van Oevelen, D., Soetaert, K., Middelburg, J. J., and Vanreusel, A.: Nutritional importance of benthic bacteria for deep-sea nematodes from the Arctic ice margin: Results of an isotope tracer experiment, Limnol. Oceanogr., 55, 1977-1989, doi:10.4319/lo.2010.55.5.1977, 2010.

Hall, R. O. and Meyer, J. L.: The trophic significance of bacteria in a detritus-based stream food web, Ecology, 79, 1995-2012, doi:10.1890/0012-9658(1998)079[1995:TTSOBI]2.0.CO;2, 1998.

Hamilton, S. K., Tankm J. L., Raikow, D. E., Siler, E. R., Dorn N. J., and Leonard, N. E.: The role of instream vs allochthonous N in stream food webs: Modeling the results of an isotope addition experiment, J. North Am. Benthol. Soc., 23, 429-448, 2004.

Hannides, C. C. S., Popp, B. N., Landry, M. R., and Graham, B. S.: Quantification of zooplankton trophic position in the North Pacific Subtropical Gyre using stable nitrogen isotopes, Limnol. Oceanogr., 54, 50-61, doi:10.4319/lo.2009.54.1.0050, 2009.

Hansen, T., Burmeister, A., and Sommer, U.: Simultaneous delta N-15, delta C-13 and delta S-34 measurements of low-biomass samples using a technically advanced high sensitivity elemental analyzer connected to an isotope ratio mass spectrometer, Rapid Commun. Mass Sp., 23, 3387-3393, doi:10.1002/rcm.4267, 2009.

Hayes, J. M.: Fractionation of carbon and hydrogen isotopes in biosynthetic processes, in: Organic geochemistry of contempo- raneous and ancient sediments, edited by: Valley, J. S. and Cole, D. R., Mineralogical Society of America, 225-277, 2001.

Herman, P. M. J., Middelburg, J. J., Widdows, J., Lucas, C. H., and Heip, C. H. R.: Stable isotopes' as trophic tracers: combining field sampling and manipulative labelling of food resources for macrobenthos, Mar. Ecol.-Prog. Ser., 204, 79-92, doi:10.3354/meps204079, 2000.

Hochberg, M. E. and Lawton, J. H.: Competition between Kingdoms, Trends Ecol. Evol., 5, 367-371, doi:10.1016/01695347(90)90097-W, 1990.

Holmes, R. M., Peterson, B. J., Deegan, L., Hughes, J., and Fry, B.: Nitrogen biogeochemistry in the oligohaline zone of a New England estuary, Ecology, 81, 416-432, 2000.

Hughes, J. E., Deegan, L. A., Peterson, B. J., Holmes, R. M., and Fry, B.: Nitrogen flow through the food web in the oligohaline zone of a new England estuary, Ecology, 81, 433-452, doi:10.1890/0012-9658(2000)081[0433:NFTTFW]2.0.CO;2, 2000.

Karlsson, J., Berggren, M., Ask, J., Bystrom, P., Jonsson, A., Laudon, H., and Jansson, M.: Terrestrial organic matter support of lake food webs: Evidence from lake metabolism and stable hydrogen isotopes of consumers, Limnol. Oceanogr., 57, 10421048, 2012.

Kirchman, D. L.: The Uptake of Inorganic Nutrients by Heterotrophic Bacteria, Microb. Ecol., 28, 255-271, doi:10.1007/BF00166816, 1994.

Krumins, J. A., van Oevelen, D., Bezemer, T. M., De Deyn, G. B., Hol, W. H. G., van Donk, E., de Boer, W., de Ruiter, P. C., Middelburg, J. J., Monroy, F., Soetaert, K., Thebault, E., van de Koppel, J., van Veen, J. A., Viketoft, M., and van der Putten, W. H.: Soil and Freshwater and Marine Sediment Food Webs: Their Structure and Function, Bioscience, 63, 35-42, doi:10.1525/bio.2013.63.1.8, 2013.

Legendre, L. and Rassoulzadegan, F.: Plankton and Nutrient Dynamics in Marine Waters, Ophelia, 41, 153-172, 1995.

Lengger, S. K., Lipsewers, Y. A., de Haas, H., Sinninghe Damsté, J. S., and Schouten, S.: Lack of ${ }^{13} \mathrm{C}$-label incorporation suggests low turnover rates of thaumarchaeal intact polar tetraether lipids in sediments from the Iceland shelf, Biogeosciences, 11, 201216, doi:10.5194/bg-11-201-2014, 2014.

Lorrain A., Paulet, Y.-M., Chauvaud, L., Savoye, N., Donval, A., and Saout, C.: Differential $\partial^{13} \mathrm{C}$ and $\partial^{15} \mathrm{~N}$ signatures among scallop tissues: implications for ecology and physiology, J. Exp. Mar. Biol. Ecol., 275, 47-61, 2002.

Lubetkin, S. C. and Simenstad, C. A.: Multi-source mixing models to quantify food web sources and pathways, J. Appl. Ecol., 41, 996-1008, doi:10.1111/j.0021-8901.2004.00957.x, 2004.

Maher, D. T., Santos, I. R., Leuven, J. R. F. W., Oakes, J. M., Erler, D. V., Carvalho, M. C., and Eyre, B. D.: Novel use of cavity ring-down spectroscopy to investigate aquatic carbon cycling from microbial to ecosystem scales', Environ. Sci. Technol., 47, 12938-12945, 2013.

Marty, J. and Planas, D.: Comparison of methods to determine algal delta C-13 in freshwater, Limnol. Oceanogr.-Meth., 6, 51-63, 2008.

McCallister, S. L., Bauer, J. E., Cherrier, J. E., and Ducklow, H. W.: Assessing sources and ages of organic matter supporting river and estuarine bacterial production: A multiple-isotope 
(Delta C-14, delta C-13, and delta N-15) approach, Limnol. Oceanogr., 49, 1687-1702, 2004.

McCallister, S. L. and del Giorgio, P. A.: Evidence for the respiration of ancient terrestrial organic $\mathrm{C}$ in northern temperate lakes and streams, P. Natl. Acad. Sci. USA, 109, 16963-16968, doi:10.1073/pnas.1207305109, 2012.

McCarthy, M. D., Lehman, J., and Kudela, R.: Compoundspecific amino acid delta $\mathrm{N}-15$ patterns in marine algae: Tracer potential for cyanobacterial vs. eukaryotic organic nitrogen sources in the ocean, Geochim. Cosmochim. Ac., 103, 104-120, doi:10.1016/j.gca.2012.10.037, 2013.

McClelland, J. W. and Montoya, J. P.: Trophic relationships and the nitrogen isotopic composition of amino acids in plankton, Ecology, 83, 2173-2180, doi:10.1890/00129658(2002)083[2173:TRATNI]2.0.CO;2, 2002.

Michener, R. M. and Lajtha, K. (Eds.): Stable isotopes in ecology and environmental science, Blackwell Scientific, Oxford, 2007.

Middelburg, J. J.: Chemoautotrophy in the ocean, Geophys. Res. Lett., 38, L24604, doi:10.1029/2011GL049725, 2011.

Middelburg, J. J. and Herman, P. M. J.: Organic matter processing in tidal estuaries, Mar. Chem., 106, 127-147, 2007.

Middelburg, J. J., Barranguet, C., Boschker, H. T. S., Herman, P. M. J., Moens, T., and Heip, C. H. R.: The fate of intertidal microphytobenthos carbon: An in situ C-13-labeling study, Limnol. Oceanogr., 45, 1224-1234, 2000.

Minagawa, M. and Wada, E.: Stepwise Enrichment of N-15 Along Food-Chains - further Evidence and the Relation between DeltaN-15 and Animal Age, Geochim. Cosmochim. Ac., 48, 11351140, doi:10.1016/0016-7037(84)90204-7, 1984.

Miyatake, T., MacGregor, B. J., and Boschker, E.: Stable Isotope Probing Combined with Magnetic Bead Capture Hybridization of 16S rRNA: Linking Microbial Community Function to Phylogeny of Sulfate-Reducing Deltaproteobacteria in Marine Sediments, Appl. Environ. Microbiol., 75, 4927-4935, 2009.

Miyatake T., Macgregor, B. J., and Boschker, H. T.: Depth-related differences in organic substrate utilization by major microbial groups in intertidal marine sediment, Appl. Environ. Microbiol., 79, 389-392, 2013.

Molari, M., Manini, E., and Dell'Anno, A.: Dark inorganic carbon fixation sustains the functioning of benthic deep-sea ecosystems, Global Biogeochem. Cy., 27, 212-221, doi:10.1002/gbc.20030, 2013.

Moodley, L., Middelburg, J. J., Boschker, H. T. S., Duineveld, G. C. A., Pel, R., Herman, P. M. J., and Heip, C. H. R.: Bacteria and Foraminifera: key players in a short-term deep-sea benthic response to phytodetritus, Mar. Ecol.-Prog. Ser., 236, 23-29, doi:10.3354/meps236023, 2002.

Moodley, L., Middelburg, J. J., Soetaert, K., Boschker, H. T. S., Herman, P. M. J., and Heip, C. H. R.: Similar rapid response to phytodetritus deposition in shallow and deep-sea sediments, J. Mar. Res., 63, 457-469, doi:10.1357/0022240053693662, 2005.

Moore, J. W. and Semmens, B. X.: Incorporating uncertainty and prior information into stable isotope mixing models, Ecol. Lett., 11, 470-480, doi:10.1111/j.1461-0248.2008.01163.x, 2008.

Nomaki, H., Ogawa, N. O., Takano, Y., Suga, H., Ohkouchi, N., and Kitazato, H.: Differing utilization of glucose and algal particulate organic matter by deep-sea benthic organisms of Sagami Bay, Japan, Mar. Ecol.-Prog. Ser., 431, 11-24, doi:10.3354/meps09144, 2011
Norrman, B., Zweifel, U. L., Hopkinson, C. S., and Fry, B.: Production and utilization of dissolved organic carbon during an experimental diatom bloom, Limnol. Oceanogr., 40, 898-907, 1995.

Oakes, J. M., Eyre, B. D., Middelburg, J. J., and Boschker, H. T. S.: Composition, production, and loss of carbohydrates in subtropical shallow subtidal sandy sediments: Rapid processing and long-term retention revealed by C-13-labeling, Limnol. Oceanogr., 55, 2126-2138, doi:10.4319/lo.2010.55.5.2126, 2010.

Oakes, J. M., Eyre, B. D., and Middelburg, J. J.: Transformation and fate of microphytobenthos carbon in subtropical shallow subtidal sands: A C-13-labeling study, Limnol. Oceanogr., 57, 18461856, doi:10.4319/lo.2012.57.06.1846, 2012.

Pace, M. L., Cole, J. J., Carpenter, S. R., Kitchell, J. F., Hodgson, J. R., Van de Bogert, M. C., Bade, D. L., Kritzberg, E. S., and Bastviken, D.: Whole-lake carbon-13 additions reveal terrestrial support of aquatic food webs, Nature, 427, 240-243, doi:10.1038/nature02227, 2004.

Pace, M. L., Carpenter, S. R., Cole, J. J., Coloso, J. J., Kitchell, J. F., Hodgson, J. R., Middelburg, J. J., Preston, N. D., Solomon, C. T., and Weidel, B. C.: Does terrestrial organic carbon subsidize the planktonic food web in a clear-water lake?, Limnol. Oceanogr., 52, 2177-2189, doi:10.4319/lo.2007.52.5.2177, 2007.

Pacella, S. R., Lebreton, B., Richard, P., Phillips, D., DeWitt, T. H., and Niquil, N.: Incorporation of diet information derived from Bayesian stable isotope mixing models into mass-balanced marine ecosystem models: A case study from the Marennes-Oléron Estuary, France, Ecol. Model., 267, 127-137, 2013.

Parnell, A. C., Inger, R., Bearhop, S., and Jackson, A. L.: Source Partitioning Using Stable Isotopes: Coping with Too Much Variation, Plos One, 5, e9672, doi:10.1371/journal.pone.0009672, 2010.

Pel, R., Hoogveld, H., and Floris, V.: Using the hidden isotopic heterogeneity in phyto- and zooplankton to unmask disparity in trophic carbon transfer, Limnol. Oceanogr., 48, 2200-2207, 2003.

Peterson, B. J. and Fry, B.: Stable Isotopes in Ecosystem Studies, Annu. Rev. Ecol. Syst., 18, 293-320, doi:10.1146/annurev.ecolsys.18.1.293, 1987.

Phillips, D. L.: Converting isotope values to diet composition: the use of mixing models, J. Mammal., 93, 342-352, doi:10.1644/11-MAMM-S-158.1, 2012.

Phillips, D. L. and Gregg, J. W.: Uncertainty in source partitioning using stable isotopes, Oecologia, 127, 171-179, doi:10.1007/s004420000578, 2001.

Phillips, D. L. and Gregg, J. W.: Source partitioning using stable isotopes: coping with too many sources, Oecologia, 136, 261269, doi:10.1007/s00442-003-1218-3, 2003.

Phillips, D. L. and Koch, P. L.: Incorporating concentration dependence in stable isotope mixing models, Oecologia, 130, 114-125, doi:10.1007/s004420100786, 2002.

Phillips, D. L., Newsome, S. D., and Gregg, J. W.: Combining sources in stable isotope mixing models: alternative methods, Oecologia, 144, 520-527, doi:10.1007/s00442-004-1816-8, 2005.

Polis, G. A., Anderson, W. B., and Holt, R. D.: Toward an integration of landscape and food web ecology: The dynamics of spatially subsidized food webs, Annu. Rev. Ecol. Syst., 28, 289-316, doi:10.1146/annurev.ecolsys.28.1.289, 1997. 
Post, D. M.: Using stable isotopes to estimate trophic position: Models, methods, and assumptions, Ecology, 83, 703-718, doi:10.2307/3071875, 2002.

Riebesell, U., Revill, A. T., Holdsworth, D. G., and Volkman, J. K.: The effects of varying $\mathrm{CO}_{2}$ concentration on lipid composition and carbon isotope fractionation in Emiliania huxleyi, Geochim. Cosmochim. Ac., 64, 4179-4192, 2000.

Rose, K. A., Allen, J. I., Artioli, Y., Barange, M., Blackford, J., Carlotti, F., Cropp, R., Daewel, U., Edwards, K., Flynn, K., Hill, S. L., HilleRisLambers, R., Huse, G., Mackinson, S., Megrey, B., Moll, A., Rivkin, R., Salihoglu, B., Schrum, C., Shannon, L., Shin, Y., Smith, S. L., Smith, C., Solidoro, C., St John, M., and Zhou, M.: End-To-End Models for the Analysis of Marine Ecosystems: Challenges, Issues, and Next Steps, Marine and Coastal Fisheries, 2, 115-130, doi:10.1577/C09-059.1, 2010.

Rossi, F., Vos, M., and Middelburg, J. J.: Species identity, diversity and microbial carbon flow in reassembling macrobenthic communities, Oikos, 118, 503-512, doi:10.1111/j.16000706.2009.17112.x, 2009.

Salihoglu, B., Neuer, S., Painting, S., Murtugudde, R., Hofmann, E. E., Steele, J. H., Hood, R. R., Legendre, L., Lomas, M. W., Wiggert, J. D., Ito, S., Lachkar, Z., Hunt, G. L.,Jr., Drinkwater, K. F., and Sabine, C. L.: Bridging marine ecosystem and biogeochemistry research: Lessons and recommendations from comparative studies, J. Marine Syst., 109, 161-175, doi:10.1016/j.jmarsys.2012.07.005, 2013.

Sarmiento, G. L. and Gruber, N.: Ocean biogeochemical dynamics, Princeton University Press, 503 pp., 2006.

Schell, D. M.: C-13 and C-14 Abundances in Alaskan Aquatic Organisms - Delayed Production from Peat in Arctic Food Webs, Science, 219, 1068-1071, doi:10.1126/science.219.4588.1068, 1983.

Schouten, S., Klein Breteler, W. C. M., Blokker, P., Schogt, N., Rijpstra, W. I. C., Grice, K., Baas, M., and Sinninghe Damsté, J. S.: Biosynthetic effects on the stable carbon isotopic composition of algal lipids: implications for deciphering the carbon isotopic biomarker record, Geochim. Cosmochim. Ac, 62, 13971406, 1998.

Semmens, B. X., Ward, E. J., Moore, J. W., and Darimont, C. T.: Quantifying Inter- and Intra-Population Niche Variability Using Hierarchical Bayesian Stable Isotope Mixing Models, Plos One, 4, e6187, doi:10.1371/journal.pone.0006187, 2009.

Sessions, A. L., Burgoyne, T. W., Schimmelmann, A., and Hayes, J. M.: Fractionation of hydrogen isotopes in lipid biosynthesis, Org. Geochem., 30, 1193-1200, doi:10.1016/S0146-6380(99)000947, 1999.

Smith, B. N. and Epstein, S.: Biogeochemistry of Stable Isotopes of Hydrogen and Carbon in Salt Marsh Biota, Plant Physiol., 46, 738-742, doi:10.1104/pp.46.5.738, 1970.

Solomon, C. T., Cole, J. J., Doucett, R. R., Pace, M. L., Preston, N. D., Smith, L. E., and Weidel, B. C.: The influence of environmental water on the hydrogen stable isotope ratio in aquatic consumers, Oecologia, 161, 313-324, doi:10.1007/s00442-0091370-5, 2009.

Solomon, C. T., Carpenter, S. R., Clayton, M. K., Cole, J. J., Coloso, J. J., Pace, M. L., Vander Zanden, M. J., and Weidel, B. C.: Terrestrial, benthic, and pelagic resource use in lakes: results from a three-isotope Bayesian mixing model, Ecology, 92, 1115-1125, 2011.
Thurber, A. R., Levin, L. A., Orphan, V. J., and Marlow, J. J.: Archaea in metazoan diets: implications for food webs and biogeochemical cycling, ISME J., 6, 1602-1612, doi:10.1038/ismej.2012.16, 2012.

Travers, M., Shin, Y.-J., Jennings, S., and Cury, P.: Towards end-toend models for investigating the effects of climate and fishing in marine ecosystems, Prog. Oceanogr., 75, 751-770, 2007.

Van den Meersche, K., Middelburg, J. J., Soetaert, K., van Rijswijk, P., Boschker, H. T. S., and Heip, C. H. R.: Carbon-nitrogen coupling and algal-bacterial interactions during an experimental bloom: Modeling a C-13 tracer experiment, Limnol. Oceanogr., 49, 862-878, 2004.

Van den Meersche, K., Soetaert, K., and Middelburg, J. J.: A Bayesian compositional estimator for microbial taxonomy based on biomarkers, Limnol. Oceanogr.-Meth., 6, 190-199, 2008.

Van den Meersche, K., Van Rijswijk, P., Soetaert, K., and Middelburg, J. J.: Autochthonous and allochthonous contributions to mesozooplankton diet in a tidal river and estuary: Integrating carbon isotope and fatty acid constraints, Limnol. Oceanogr., 54, 62-74, doi:10.4319/lo.2009.54.1.0062, 2009.

Van den Meersche, K., Soetaert, K., and Middelburg, J. J.: Plankton dynamics in an estuarine plume: a mesocosm C13 and N-15 tracer study, Mar. Ecol.-Prog. Ser., 429, 29-43, doi:10.3354/meps09097, 2011.

Van Engeland, T., De Kluijver, A., Soetaert, K., Meysman, F. J. R., and Middelburg, J. J.: Isotope data improve the predictive capabilities of a marine biogeochemical model, Biogeosciences Discuss., 9, 9453-9486, doi:10.5194/bgd-9-9453-2012, 2012.

van Nugteren, P., Herman, P. M. J., Moodley, L., Middelburg, J. J., Vos, M., and Heip, C. H. R.: Spatial distribution of detrital resources determines the outcome of competition between bacteria and a facultative detritivorous worm, Limnol. Oceanogr., 54, 1413-1419, doi:10.4319/1o.2009.54.5.1413, 2009.

van Oevelen, D., Moodley, L., Soetaert, K., and Middelburg, J. J.: The trophic significance of bacterial carbon in a marine intertidal sediment: Results of an in situ stable isotope labeling study, Limnol. Oceanogr., 51, 2349-2359, 2006a.

van Oevelen, D., Soetaert, K., Middelburg, J. J., Herman, P. M. J., Moodley, L., Hamels, I., Moens, T., and Heip, C. H. R.: Carbon flows through a benthic food web: Integrating biomass, isotope and tracer data, J. Mar. Res., 64, 453-482, doi:10.1357/002224006778189581, 2006b.

van Oevelen, D., Van den Meersche, K., Meysman, F. J. R., Soetaert, K., Middelburg, J. J., and Vezina, A. F.: Quantifying Food Web Flows Using Linear Inverse Models, Ecosystems, 13, 32-45, doi:10.1007/s10021-009-9297-6, 2010.

Van Oevelen, D., Soetaert, K., and Heip, C. H. R.: Carbon flows in the benthic food web of the Porcupine Abyssal Plain: The (un)importance of labile detritus in supporting microbial and faunal carbon demands, Limnol. Oceanogr., 7, 645-664, 2012.

Vander Zanden, M. J. and Rasmussen, J. B.: Variation in delta N15 and delta $\mathrm{C}-13$ trophic fractionation: Implications for aquatic food web studies, Limnol. Oceanogr., 46, 2061-2066, 2001.

Vander Zanden, M. J., Casselman, J. M., and Rasmussen, J. B.: Stable isotope evidence for the food web consequences of species invasions in lakes, Nature, 401, 464-467, doi:10.1038/46762, 1999. 
Vanderklift, M. A. and Ponsard, S.: Sources of variation in consumer-diet delta(15)N enrichment: a meta-analysis, Oecologia, 136, 169-182, doi:10.1007/s00442-003-1270-z, 2003.

Veuger, B., Middelburg, J. J., Boschker, H. T. S., and Houtekamer, M.: Analysis of N-15 incorporation into D-alanine: A new method for tracing nitrogen uptake by bacteria, Limnol. Oceanogr.-Meth., 3, 230-240, 2005.

Veuger, B., Eyre, B. D., Maher, D., and Middelburg, J. J.: Nitrogen incorporation and retention by bacteria, algae, and fauna in a subtropical intertidal sediment: An in situ N-15-labeling study, Limnol. Oceanogr., 52, 1930-1942, doi:10.4319/lo.2007.52.5.1930, 2007.

Vogel, C., Mueller, C. W., Höschen, C., Buegger, F., Heister, K., Schulz, S., Schloter, M., and Kögel-Knabner, I.: Submicron structures provide preferential spots for carbon and nitrogen sequestration in soils, Nat. Commun., 5, 2947, doi:10.1038/ncomms3947, 2014.

Wagner, M.: Single-Cell Ecophysiology of Microbes as Revealed by Raman Microspectroscopy or Secondary Ion Mass Spectrometry Imaging, Annu. Rev. Microbiol., 63, 411-429, doi:10.1146/annurev.micro.091208.073233, 2009.

Witte, U., Wenzhofer, F., Sommer, S., Boetius, A., Heinz, P., Aberle, N., Sand, M., Cremer, A., Abraham, W. R., Jorgensen, B. B., and Pfannkuche, O.: In situ experimental evidence of the fate of a phytodetritus pulse at the abyssal sea floor, Nature, 424, 763766, doi:10.1038/nature01799, 2003.
Wolf, N., Carleton, S. A., and del Rio, C. M.: Ten years of experimental animal isotopic ecology, Funct. Ecol., 23, 17-26, doi:10.1111/j.1365-2435.2009.01529.x, 2009.

Woulds, C., Cowie, G. L., Levin, L. A., Andersson, J. H., Middelburg, J. J., Vandewiele, S., Lamont, P. A., Larkin, K. E., Gooday, A. J., Schumacher, S., Whitcraft, C., Jeffreys, R. M., and Schwartz, M.: Oxygen as a control on seafloor biological communities and their roles in sedimentary carbon cycling, Limnol. Oceanogr., 52, 1698-1709, doi:10.4319/lo.2007.52.4.1698, 2007.

Woulds, C., Andersson, J. H., Cowie, G. L., Middelburg, J. J., and Levin, L. A.: The short-term fate of organic carbon in marine sediments: Comparing the Pakistan margin to other regions, DeepSea Ress. Pt. II, 56, 393-402, doi:10.1016/j.dsr2.2008.10.008, 2009.

Zhang, X., Gillespie, A. L., and Sessions, A. L.: Large $\mathrm{D} / \mathrm{H}$ variations in bacterial lipids reflect central metabolic pathways, P. Natl. Acad. Sci. USA, 106, 12580-12586, doi:10.1073/pnas.0903030106, 2009.

Zigah, P. K., Minor, E. C., Werne, J. P., and Leigh McCallister, S.: An isotopic $\left(\Delta^{14} \mathrm{C}, \delta^{13} \mathrm{C}\right.$, and $\left.\delta^{15} \mathrm{~N}\right)$ investigation of the composition of particulate organic matter and zooplankton food sources in Lake Superior and across a size-gradient of aquatic systems, Biogeosciences, 9, 3663-3678, doi:10.5194/bg-9-36632012, 2012. 